\title{
Interactive effects of 1, 25-dihydroxyvitamin D3 and soy protein extract (SPE) on oral cancer growth in vitro: evidence for potential functional relationships.
}

\author{
Karl Kingsley ${ }^{1}$, Mark A. Keiserman ${ }^{2}$, Christine J. Bergman ${ }^{3}$ \\ ${ }^{1}$ Department of Biomedical Sciences, School of Dental Medicine, University of Nevada, Las \\ Vegas, 1001 Shadow Lane, Las Vegas, Nevada, 89106, USA; ${ }^{2}$ Department of Nutritional \\ Sciences, University of Medicine and Dentistry of New Jersey, 65 Bergen St \#149, Newark, New \\ Jersey, 07107, USA; ${ }^{3}$ Department of Food and Beverage, Harrah Hotel College, University of \\ Nevada, Las Vegas, 4505 Maryland Parkway, Las Vegas, Nevada, 89154, USA
}

Corresponding Author: Karl Kingsley, Department of Biomedical Sciences, School of Dental Medicine, University of Nevada, Las Vegas, 1001 Shadow Lane, Las Vegas, Nevada, 89106, USA

Submission date: April 10, 2013; Acceptance date: June 5, 2013; Publication date: June 11, 2013

\begin{abstract}
:
Background: Previous studies have found specific soy isoflavones (Genistein, Daidzein, Glycitein) demonstrate anti-tumor properties against several cancer types, including oral cancer. Few studies have evaluated whole soy extract, containing a combination of these isoflavones and other bioreactive compounds, which may function synergistically and more effectively against oral cancers. Preliminary work by this group has now demonstrated whole soy protein extract (SPE) inhibits oral cancer cell growth specifically and selectively, through independent cellcycle and apoptotic pathways. However, more recent evidence now suggests that ingestion of vitamin $\mathrm{D}_{3}$, either in dietary foods or supplements may potentiate the activity of soy components and their anti-tumor effects.
\end{abstract}

Objective: The primary goal of this study was to investigate the interactive and inter-connected effects of 1,25-dihydroxyvitamin $\mathrm{D}_{3}$ administration with the anti-proliferative effects of whole soy protein extract (SPE) on oral cancer and normal cell lines in vitro.

Methods: Three oral squamous cell carcinoma cell lines (SCC15, SCC25, and CAL27) were treated with 1, 25-dihydroxy Vitamin $\mathrm{D}_{3}$ at physiological concentrations (10-125 nmol). Cell growth was then compared with cell treatment using soy protein extract (SPE) within the normal physiologic range $(0-10 \mu \mathrm{M} / \mathrm{L})$. Interactive effects were then evaluated using co-administration of SPE and 1, 25-dihydroxy Vitamin $\mathrm{D}_{3}$. Quantitative RT-PCR was performed at various time points to determine any changes in mRNA expression for key cell cycle and apoptotic signaling 
pathway regulators, including p53, c-myc, ornithine decarboxylase (ODC), caspase-2, caspase8 , and bax.

Results: Administration of 1, 25-dihydroxy Vitamin $\mathrm{D}_{3}$ induced distinct dose-dependent, growth-inhibitory effects in all three oral cancer cell lines examined. These inhibitory effects were comparable to the overall range of growth inhibition induced by SPE. However, the combined effects of co-administration were far greater, suggesting the presence of synergistic relationships between these components. In addition, these results indicate that either treatment alone appeared to modulate mRNA expression of oral cancer cell-cycle promoters $c$-myc and $O D C$, as well as the caspase-dependent apoptosis pathway, while only 1, 25-dihydroxy Vitamin $\mathrm{D}_{3}$ administration appeared to influence the bax pathway.

Conclusion: These results suggest that co-administration with 1, 25-dihydroxy Vitamin $\mathrm{D}_{3}$ and SPE may enhance their anti-tumor effects. This study may help to explain, in part, why balanced diets rich in fruits, vegetables, and soy protein, are associated with protection against development and progression of oral cancers, although further study is needed to develop specific public health recommendations for oral cancer treatment and prevention.

Key words: vitamin D, soy extract, whole soy protein, oral cancer, growth inhibition.

\section{BACKGROUND:}

Oral cancer: The main risk factors contributing to the development of oral cancers in the United States (US) are tobacco use (in the form of smoking), and alcohol consumption, which together may be responsible for up to $80 \%$ of this cancer risk [1-3]. Another important risk factor for oral and pharyngeal cancers (OPC) is infection with the human papillomavirus (HPV), which has been identified in a significant subset of these cancers [4, 5]. More recently, evidence has demonstrated that dietary intake may account for as much as $20-25 \%$ of the variability in OCP risk, with health-protective effects and reduced incidences associated with specific dietary components such as fruits and vegetables, soy proteins, coffee, fiber, folic acid, and the vitamins A, C, D, and E [6, 7].

Diet and nutrition: In addition to these health protective and cancer preventive effects, evidence now suggests that progression of oral cancer is also intricately linked with diet and nutrition, which can modulate the influence of all three major oral cancer risk factors, as well as cellular growth [8]. For example, dietary fruit or vegetable intake separately and independently reduces oral cancer risk or progression - even after adjusting for age, gender, or tobacco use and alcohol consumption [8,9]. The efforts to identify and characterize specific dietary components with these potent chemo preventive and chemotherapeutic properties have led researchers to explore a large number of putative anti-cancer agents derived specifically from fruits, vegetables and legumes.

Oral cancer inhibition: Flavonoids and polyphenolics, carotenoids, dithioltiones, 
glucosinolates, indoles, isothiocyanates, protease inhibitors, plant sterols, allium compounds, limonenes, selenium, vitamin $\mathrm{C}$, vitamin $\mathrm{E}$, and dietary fiber all have noted inhibitory effects on oral cancer [10-12]. The majority of studies focusing on dietary prevention and therapy for oral cancer have explored the role of flavonoids, part of a large family of polyphenolic compounds made by plants [13-19]. New evidence, however, has suggested that another subclass of flavonoids highly concentrated in soybeans and soy-containing foods (isoflavones) may also exhibit potent effects specific for oral cancers [20-24].

Soy isoflavones: Many of these studies have focused on specific isoflavones derived from soy, which include Daidzein, Genistein, and Glycitein, which are capable of inhibiting growth and proliferation of oral cancers [25-27]. Although significant, these effects were observed in vitro at supraphysiologic levels ( $>10 \mu \mathrm{mol} / \mathrm{L}$ ), which may be neither safe (in vivo) nor feasible through dietary consumption or nutritional supplementation. This group was among the first to demonstrate that soy proteins, in combination, may be useful and effective against oral cancers at concentrations that approximate physiologic serum levels $(0-2 \mu \mathrm{mol} / \mathrm{L})$ achievable through dietary or supplement intake, which may help to explain why diets rich in fruits, vegetables, and soy protein are associated with protection against development and progression of oral cancers [24]. There is some evidence suggesting that synergistic effects of multiple isoflavones in whole soy foods and soy extracts may be responsible for preventing the negative side effects observed with single agent administration to normal cells, as well as the expression of anti-cancer effects at much lower serum concentrations [28, 29].

Soy interactions with Vitamin D3: Researchers have focused on the direct, antitumor properties of soy isoflavones on oral cancers; however, few studies have evaluated the interactive effect of whole soy (or soy-derived isoflavones) via regulation of P450 enzymes, involved in the metabolism of Vitamin D. However, there is evidence to suggest this may be a significant regulatory pathway of anti-cancer action as the few studies completed to date have demonstrated that soy protein (both in vivo and in vitro) directly influences the expression of P450 enzymes in other cancers - thereby regulating cellular Vitamin D metabolism [30-32]. For example, CYP24 is often highly expressed in many cancers, which degrades newly synthesized or serum-derived levels of 1, 25-dihydroxyvitamin D3 [33-36]. These studies suggest that dietary intake of soy may result in a consistent down-regulation of CYP24, thereby enabling the functions and anticancer properties of Vitamin D [32, 37].

Vitamin D and oral cancer: Consistent with these laboratory findings, large-scale population studies clearly demonstrated that low serum vitamin D levels and vitamin D deficiencies are associated with much higher cancer risk [38, 39]. More specifically, epidemiologic and casecontrolled studies have confirmed that low vitamin D levels and deficiency are strongly associated with OPC risk [40, 41]. The primary mechanism of Vitamin D action is mediated through binding of either $1,25(\mathrm{OH})_{2} \mathrm{D}$ (active form) or $25(\mathrm{OH}) \mathrm{D}$ (less active form) to the vitamin D receptor (VDR), which is a member of the nuclear receptor super family of steroid and thyroid hormones with gene regulatory and consequent anti-proliferative properties [42, 43]. 
Vitamin D mechanism: Binding of $1,25(\mathrm{OH})_{2} \mathrm{D}$ to the VDR (either in the cell nucleus or cytoplasm) promotes association of the VDR- $1,25(\mathrm{OH})_{2} \mathrm{D}$ complex with the retinoid $\mathrm{X}$ receptor (RXR) [41, 42]. The 1, 25(OH)2D-VDR-RXR complex binds to vitamin D-response elements in DNA which operate to initiate gene transcription. Activation of the VDR by $1,25(\mathrm{OH})_{2} \mathrm{D}$ can restore or enhance pro-apoptotic effects in different cancer cells through transcriptional activation of bax and p-calpain, two effective pro-apoptotic proteins [44, 45]. Although much is known about these effects in other cancers, few studies to date have evaluated Vitamin D in oral cancers $[46,47]$.

Evidence for interactive effects: There is now evidence that many oral cancers may, in fact, exert their effects on cellular Vitamin D metabolism by changing the availability of (or affecting the ability to bind to) the VDR. New evidence demonstrates that some oral cancers may exhibit reduced VDR expression [48, 49]. In addition, Ras activation (common in many oral cancers) might also impair Vitamin D-mediated transcription. Cytochrome p450 (CYP24, the enzyme responsible for degrading vitamin D) exhibited the highest up-regulation (196-fold increase) from a screening of more than 4,500 genes in one oral cancer cell line [47]. This may provide some evidence consistent with the observation that CYP24 mutations may lower oral cancer risk compared with wild type, after adjusting for age, gender, alcohol consumption, and smoking status [50].

Based upon this information, the overall objective of this study is to evaluate the anticancer properties of soy protein extract (SPE), which is available as a dietary supplement and most closely resembles the whole soy food that most US adults are likely to consume. The effects of SPE against well-characterized oral cancer cell lines will be evaluated using in vitro analysis methods. These experiments will be performed in conjunction with administration of Vitamin D to determine the interactive effects of SPE on Vitamin D-induced oral cancer growth inhibition.

Based upon previous work that determined SPE and Vitamin D are each, independently sufficient to mediate the proliferative phenotypes of these cancers in this experimental model, the working hypothesis is that co-administration will synergistically amplify these effects. Using in vitro analysis methods, any quantitative differences in viability and growth of oral cancer cells will be measured. The specific aims will be to characterize the inhibition of oral cancer proliferation induced by SPE administration in combination with Vitamin D, as well as any effects on cellular viability. The activation and expression of the apoptotic regulators, caspase-2, caspase-8, and bax, will also be assessed.

\section{MATERIALS AND METHODS:}

Cell culture and cell lines: The human oral squamous cell carcinoma cell lines, CAL 27 (CRL2095) and SCC25 (CRL-1628), were obtained from American Type Culture Collection (ATCC: Manassas, VA). CAL 27 cells were maintained in Dulbecco's Modified Eagle's Medium (DMEM) with $4.0 \mathrm{mM}$ L-Glutamine adjusted to contain $3.7 \mathrm{~g} / \mathrm{L}$ sodium bicarbonate, $4.5 \mathrm{~g} / \mathrm{L}$ glucose, and $110 \mathrm{mg} / \mathrm{L}$ sodium pyruvate, obtained from HyClone (Logan, UT). SCC25 cells were maintained in a 1:1 mixture of DMEM and Ham's F12 medium with $2.5 \mathrm{mM}$ L-Glutamine, 
modified to contain $15 \mathrm{mM}$ 4-2-hydroxyethyl-1-piperazineethanesulfonic acid (HEPES), $0.5 \mathrm{mM}$ sodium pyruvate, and $1.2 \mathrm{~g} / \mathrm{L}$ sodium bicarbonate.

The normal oral gingival fibroblast cell line, HGF-1 (CRL-2014), was also obtained from American Type Culture Collection (ATCC: Manassas, VA). HGF-1 cells were maintained in DMEM with $4 \mathrm{mM}$ L-Glutamine, adjusted to contain $3.7 \mathrm{~g} / \mathrm{L}$ sodium bicarbonate and $4.5 \mathrm{~g} / \mathrm{L}$ glucose, from HyClone (Logan, UT). All cell culture media was supplemented with $1 \%$ Penicillin (10,000 units/mL)-Streptomycin $(10,000 \mu \mathrm{g} / \mathrm{mL})$ solution and $10 \%$ fetal bovine serum (FBS) obtained from HyClone (Logan, UT). Cells were cultured in $75 \mathrm{~cm}^{2}$ BD Falcon tissueculture treated flasks (Bedford, MA) at $37^{\circ} \mathrm{C}$ and $5 \% \mathrm{CO}_{2}$ in humidified chambers.

Materials: 1 , 25-dihydroxyvitamin $\mathrm{D}_{3}\left(\mathrm{VitD}_{3}\right)$ was obtained from GNC Preventive Nutrition® (Pittsburgh, PA). Proliferation and viability assays were performed in the appropriate complete media, with and without the addition of $\operatorname{VitD}_{3}(10,50$ and $125 \mathrm{nmol})$. This concentration range $(25-312.5 \mathrm{ng} / \mathrm{mL})$ approximates the physiologic concentrations of the less active form of $\mathrm{VitD}_{3}$, but supraphysiologic concentrations of the active form, which allowed for short-term in vitro effects to be observed [42, 51]. This also enabled comparison with the only other studies examining OPC cell lines [46, 47], which utilized similar concentration ranges $(1,10,100 \mathrm{nmol}$ or $2.5,125,250 \mathrm{ng} / \mathrm{mL}$ ).

Soy protein extract (SPE) was obtained from GNC Preventive Nutrition ${ }^{\circledR}$ (Pittsburgh, PA). Equivalent amounts of SPE were used to approximate the low- $(10 \mu \mathrm{g} / \mathrm{mL})$, mid- $(50 \mu \mathrm{g} / \mathrm{mL})$, and high-range $(100 \mu \mathrm{g} / \mathrm{mL})$ concentrations of flavonoid extracts utilized in prior in vitro studies $[16,17,19]$, which were 10,50 , and $100 \mu \mathrm{g} / \mathrm{mL}$. In addition to total SPE, the concentration of soy isoflavones for each experimental condition was also calculated to determine if these concentrations were within the normal physiologic range $(0-10 \mu \mathrm{M} / \mathrm{L})$.

Quantitative analysis provided by GNC demonstrated each gram of SPE contained $0.86-$ $2.6 \mathrm{mg}$ of isoflavones, with $0.30-0.91 \mathrm{mg} / \mathrm{g}$ Daidzein (all forms), 0.52-1.56 mg/g Genistein (all forms), and $0.04-0.13 \mathrm{mg} / \mathrm{g}$ Glycitein (all forms), resulting in an approximate ratio of 7:12:1 (Daidzein, Genistein, Glycitein, respectively). The proportional molecular weights (MW) of the soy isoflavones in the SPE were calculated to be:

$$
\begin{aligned}
\text { Daidzein }(\mathrm{MW}=254.24) \times 7 & =1779.68 \\
\text { Genistein }(\mathrm{MW}=270.2) \times 12 & =3242.40 \\
\text { Glycitein }(\mathrm{MW}=284.24) \times 1 & =284.24 \\
\text { Total }(\text { sum }) \quad & 5306.32 / 20=\text { proportional, averaged MW } 265.31
\end{aligned}
$$

To derive physiologic concentration, the total amount of SPE used (mg/L) is multiplied by the percentage of isoflavones contained within this amount; the proportional amount of total isoflavone is then divided by the averaged MW to yield moles $(\mathrm{M} / \mathrm{L})$; this amount is converted to derive final isoflavone concentration $(\mu \mathrm{mol} / \mathrm{L})$ as follows:

$10 \mu \mathrm{g} / \mathrm{mL}$ SPE $=10 \mathrm{mg} / \mathrm{L}$ or $0.01 \mathrm{~g} \mathrm{SPE}$

$0.01 \mathrm{~g} \mathrm{SPE}(0.0026$ isoflavone concentration per $\mathrm{g} / \mathrm{SPE})=0.000026 \mathrm{~g}$ total isoflavone 
$0.000026 \mathrm{~g} / 265.31 \mathrm{MW}=0.00000000979 \mathrm{~mol} / \mathrm{L}(1,000,000)=0.0979 \mu \mathrm{mol} / \mathrm{L}$

$10 \mu \mathrm{g} / \mathrm{mL} \mathrm{SPE}=0.0979 \mu \mathrm{mol} / \mathrm{L}$ total isoflavone $\quad=\quad$ approximately $0.1 \mu \mathrm{mol} / \mathrm{L}$

$50 \mu \mathrm{g} / \mathrm{mL} \mathrm{SPE}=0.4895 \mu \mathrm{mol} / \mathrm{L} \mathrm{L}$ total isoflavone $=$ approximately $0.5 \mu \mathrm{mol} / \mathrm{L}$

$100 \mu \mathrm{g} / \mathrm{mL} \mathrm{SPE}=0.979 \mu \mathrm{mol} / \mathrm{L}$ total isoflavone $\quad=\quad$ approximately $1.0 \mu \mathrm{mol} / \mathrm{L}$

Previous studies have demonstrated normal physiological levels of total plasma soy isoflavones vary between 1 and $2 \mu \mathrm{mol} / \mathrm{L}$ [52, 53], although higher concentrations have been observed among Asian populations [54, 55]. Based upon this information, the range of soy isoflavone concentrations utilized in this study $(0.1-1.0 \mu \mathrm{mol} / \mathrm{L})$ was within the normal physiologic range. The individual concentrations for the active soy isoflavones are as follows:

$\begin{array}{lccc} & \frac{\mathbf{1 0} \boldsymbol{\mu g} / \mathbf{m L}}{2 \mu \mathrm{M} / \mathrm{L}} & \frac{\mathbf{5 0} \boldsymbol{\mu g} / \mathbf{m L}}{10 \mu \mathrm{M} / \mathrm{L}} & \frac{\mathbf{1 0 0} \boldsymbol{\mu g} / \mathbf{m L}}{20 \mu \mathrm{M} / \mathrm{L}} \\ \text { SPE } & 0.0357 \mu \mathrm{M} / \mathrm{L} & 0.185 \mu \mathrm{M} / \mathrm{L} & 0.357 \mu \mathrm{M} / \mathrm{L} \\ \text { Daidzein } & 0.057 \mu \mathrm{M} / \mathrm{L} & 0.289 \mu \mathrm{M} / \mathrm{L} & 0.577 \mu \mathrm{M} / \mathrm{L} \\ \text { Genistein } & 0.005 \mu \mathrm{M} / \mathrm{L} & 0.023 \mu \mathrm{M} / \mathrm{L} & 0.046 \mu \mathrm{M} / \mathrm{L}\end{array}$

Proliferation: Proliferation assays were performed in the appropriate complete media, with and without the addition of SPE, $\mathrm{VitD}_{3}$ or both, prior to the start of each experimental assay. In brief, cells were plated in Corning Costar high-throughput, 96-well assay plates (Corning, NY) at a concentration of $1.2 \times 10^{4}$ cells per well, which roughly approximates $30-40 \%$ confluence per well at the onset of each assay. Proliferation was subsequently measured after three days. Cultured cells were fixed after 72 hours or day 3 using $50 \mu \mathrm{L}$ of $10 \%$ buffered formalin, and were stained with crystal violet 1\% aqueous solution (Fisher Scientific: Fair Lawn, NJ). The relative absorbance was measured at $630 \mathrm{~nm}$ using a Bio-Tek ELx808 microplate reader (Winooski, VT). Data was analyzed and graphed using Microsoft Excel (Redmond, WA) and SPSS (Chicago, IL). Three separate, independent replications of each experiment were performed.

Statistics: Comparisons of the effects of treatments were made using two-tailed $t$-tests with $\alpha=$ .05 . All samples were analyzed using two-tailed $t$-tests as departure from normality can make more of a difference in a one-tailed than in a two-tailed t test [56]. As long as the sample size is moderate (> 20) for each group, quite severe departures from normality make little practical difference in the conclusions reached from these analyses. Multiple analyses involving twosample $t$-tests have higher probability of Type I errors, leading to false rejection of the null hypothesis $\left(\mathrm{H}_{0}\right)$. To confirm the effects of these experiments, one-way analysis of variance (ANOVA) was used to assess statistical significance, $p<0.05$. In addition, the data were analyzed after each experimental set to determine whether if the growth inhibition was normally distributed. This analysis revealed the cumulative probably of these data falling within a normal distribution was 0.99379 or $99.38 \%(\alpha=0.0125)$. Because the outcome measures were tested against a three (individual tests of SPE or VitD ${ }_{3}$ concentration) or four (combination of SPE and 
$\mathrm{VitD}_{3}$ concentrations) predictors, a Bonferroni-adjusted significance level of $\alpha=0.0125$ was used to account for the increased possibility of type I error $(\alpha=0.05 / 4=0.0125)$.

Survival and viability: Prior to plating cells for proliferation assays, aliquots of trypsinized cells were stained using Trypan Blue (Sigma: St. Louis, MO), and live cells were enumerated by counting the number of Trypan-blue negative cells using a VWR Scientific Counting Chamber (Plainfield, NJ) and a Zeiss Axiovert 40 inverted microscope (Gottingen, Germany). At each time point (d1-d3), several wells were processed using the Trypan stain, and live cells were enumerated using this procedure.

RT-PCR: RNA was isolated from $1.5 \times 10^{7}$ CAL27, SCC25 and SCC15 cells at baseline (day 0 ), after 24 hours (day 1), and 72 hours (day 3) following administration of $\mathrm{VitD}_{3}$ combined with SPE at the indicated concentrations; lowest concentration [L] and the Growth Inhibitory Maximum $\left(\mathrm{GI}_{\mathrm{MAX}}\right)$ or highest $[\mathrm{H}]$ concentration using ABgene Total RNA Isolation Reagent (Epsom, Surrey, UK) and the procedure recommended by the manufacturer. RT-PCR was performed on total RNA with the ABgene Reverse-iT One-Step RT-PCR Kit (ReadyMix Version) and a Mastercycler gradient thermocycler (Eppendorf: Hamburg, Germany). The following mRNA primers for glyceraldehyde 3-phosphate dehydrogenase (GAPDH) [17], p53 [17], c-myc [8], ornithine decarboxylase (ODC) [57], caspase-2 [58], caspase-8 [59], and bax [58], synthesized by SeqWright (Houston, TX), were used:

p53 forward primer, ACCAGGGCAGCTACGGTTTC;

p53 reverse primer, CCTGGGCATCCTTGAGTTCC; $c$-myc forward primer, TCCAGCTTGTACCTGCAGGATCTGA; $c-m y c$ reverse primer, CCTCCAGCAGAAGGTGATCCAGACT;

$O D C$ forward primer, AATCAACCCAGCGTTGGACAA;

$O D C$ reverse primer, ACATCACATAGTAGATCGTCG; caspase- 2 forward primer, TGGCATATAGGTTGCAGTCTCGG; caspase- 2 reverse primer, TGTTCTGTAGGCTTGGGCAGTTG; caspase -8 forward primer, GATATTGGGGAACAACTGGAC; caspase- 8 reverse primer, CATGTCATCATCCAGTTTGCA; bax forward primer, GGTTTCATCCAGGATCGAGACGG; bax reverse primer, ACAAAGATGGTCACGGTCTGCC; GAPDH FORWARD: ATCTTCCAGGAGCGAGATCC; GAPDH REVERSE: ACCACTGACACGTTGGCAGT;

RNA standard: GAPDH was obtained from control cells, human gingival fibroblasts (HGF-1) 0.3-0.5 x $10^{6}$ cells $/ \mathrm{mL}$ were used to establish the minimum threshold (CT) and saturation (CS) cycles required for calibration and concentration comparisons using relative endpoint (RE) RTPCR. GAPDH signal detection above background or threshold (CT) required a minimum of ten cycles (C10), with saturation (CS) observed at C40. Based upon this data, RE-PCR was performed at $\mathrm{C} 35$, above the lower detection limit but below the saturation limit. 
In brief, one (1) $\mu \mathrm{g}$ of template (total) RNA was used for each reaction. The reverse transcription step ran for 30 minutes at $47^{\circ} \mathrm{C}$, followed by denaturation for 2 minutes at $94^{\circ} \mathrm{C}$. Thirty-five amplification cycles were ran, consisting of 20 second denaturation at $94^{\circ} \mathrm{C}, 30$ seconds of annealing at $58^{\circ} \mathrm{C}$, and 6.5 minutes of extension at $72^{\circ} \mathrm{C}$. Final extension was run for 5 minutes at $72^{\circ} \mathrm{C}$. Reaction products were separated by gel electrophoresis using Reliant $4 \%$ NuSieve® 3:1 Plus Agarose gels (Lonza: Rockland, ME). Bands were visualized by UV illumination of ethidium-bromide (EtBr)-stained gels and captured using a Kodak Gel Logic 100 Imaging System and 1D Image Analysis Software (Eastman Kodak: Rochester, NY). Quantification of RT-PCR band densitometry was performed using Adobe (San Jose, CA) Photoshop imaging software, Image Analysis tools.

\section{RESULTS:}

A dose-dependent response relationship between growth inhibition and $\mathrm{VitD}_{3}$ administration was observed in all three oral squamous cell carcinoma cell lines (CAL27, SCC25, SCC15) with increasing concentrations resulting in more robust inhibition of cellular proliferation (Figure 1). For example, the lowest concentration $\mathrm{VitD}_{3}(10 \mathrm{nmol}$ or $2.5 \mathrm{ng} / \mathrm{mL})$ reduced growth significantly (compared with baseline controls) by $11 \%, 6.5 \%$, and $12 \%$ in CAL27, SCC25, and SCC15 cells $(p<0.05)$, respectively. Higher concentrations of $\mathrm{VitD}_{3}(50 \mathrm{nmol}$ or $125 \mathrm{ng} / \mathrm{mL})$ induced greater growth inhibition, reducing proliferation by $18.6 \%, 38.8 \%$, and $18.2 \%$, respectively ( $p<0.01)$. The highest concentration $(125 \mathrm{nmol}$ or $312.5 \mathrm{ng} / \mathrm{mL})$ induced the greatest effects, inhibiting proliferation by $29.1 \%, 43.1 \%$, and $32.1 \%$, respectively - which was determined to be the observed growth inhibitory maximum $\left(\mathrm{GI}_{\mathrm{MAX}}\right)$ concentration. Higher concentrations induced ever-diminishing effects above this concentration $150-300 \mathrm{nmol}$ or 375 $-750 \mathrm{ng} / \mathrm{mL}$ (data not shown), which approximate physiologic levels of vitamin D intoxication [51].

Growth inhibition was also observed following SPE administration among all three cell lines, although these effects were not uniform. More specifically, the lowest concentration of SPE $(10 \mu \mathrm{g} / \mathrm{mL}$ or $2 \mu \mathrm{M} / \mathrm{L})$ was sufficient to inhibit growth significantly by $25.8 \%, 20.2 \%$, and $15.2 \%$ in CAL27, SCC25, SCC15 cells, respectively $(p<0.05)$. The growth inhibitory maximum $\left(\mathrm{GI}_{\mathrm{MAX}}\right)$ concentration of SPE was observed at $50 \mu \mathrm{g} / \mathrm{mL}(10 \mu \mathrm{M} / \mathrm{L})$, which inhibited growth by $39.1 \%, 29.2 \%$, and $19.2 \%$ in CAL27, SCC25, SCC15 cells, respectively $(p<0.01)$. However, the highest concentration evaluated $(100 \mu \mathrm{g} / \mathrm{mL}$ or $20 \mu \mathrm{M} / \mathrm{L})$ was not sufficient to inhibit CAL27 growth as intensely $(-31.3 \%, p<0.01)$ and the effects on SCC25 and SCC15 were indistinguishable from those observed at $50 \mu \mathrm{g} / \mathrm{mL}(p>0.05)$. No greater effects were observed above this concentration range.

To assess any additive, interactive or synergistic effects, three-day growth assays were performed using of concomitant administration of $\mathrm{VitD}_{3}$ and SPE combining the lowest [L] and the highest $[\mathrm{H}] \mathrm{GI}_{\mathrm{MAX}}$ concentrations (Figure 2). For example, the combined effects of the lowest concentrations of $\mathrm{VitD}_{3}[\mathrm{~L}]$ and SPE [L] inhibited growth of all three cell lines more intensely than either component independently. This combination inhibited CAL27 growth by $41.8 \%$, which is greater than the effects of $\mathrm{VitD}_{3}$ [L] or SPE [L] individually $(-18.6 \%, 25.8 \%$, respectively). This combination resulted in similar growth inhibition among SCC15 cells (- 
$31.2 \%)$, which was stronger than either in isolation $(-18.2 \%, 15.2 \%$, respectively). However, this combination precipitated equivalent reductions $(-37.1 \%)$ to $\mathrm{VitD}_{3}[\mathrm{~L}](-38.8 \%)$ in $\mathrm{SCC}^{25}$ cell growth, although this was more than what was observed under SPE [L] administration (-29.1\%).

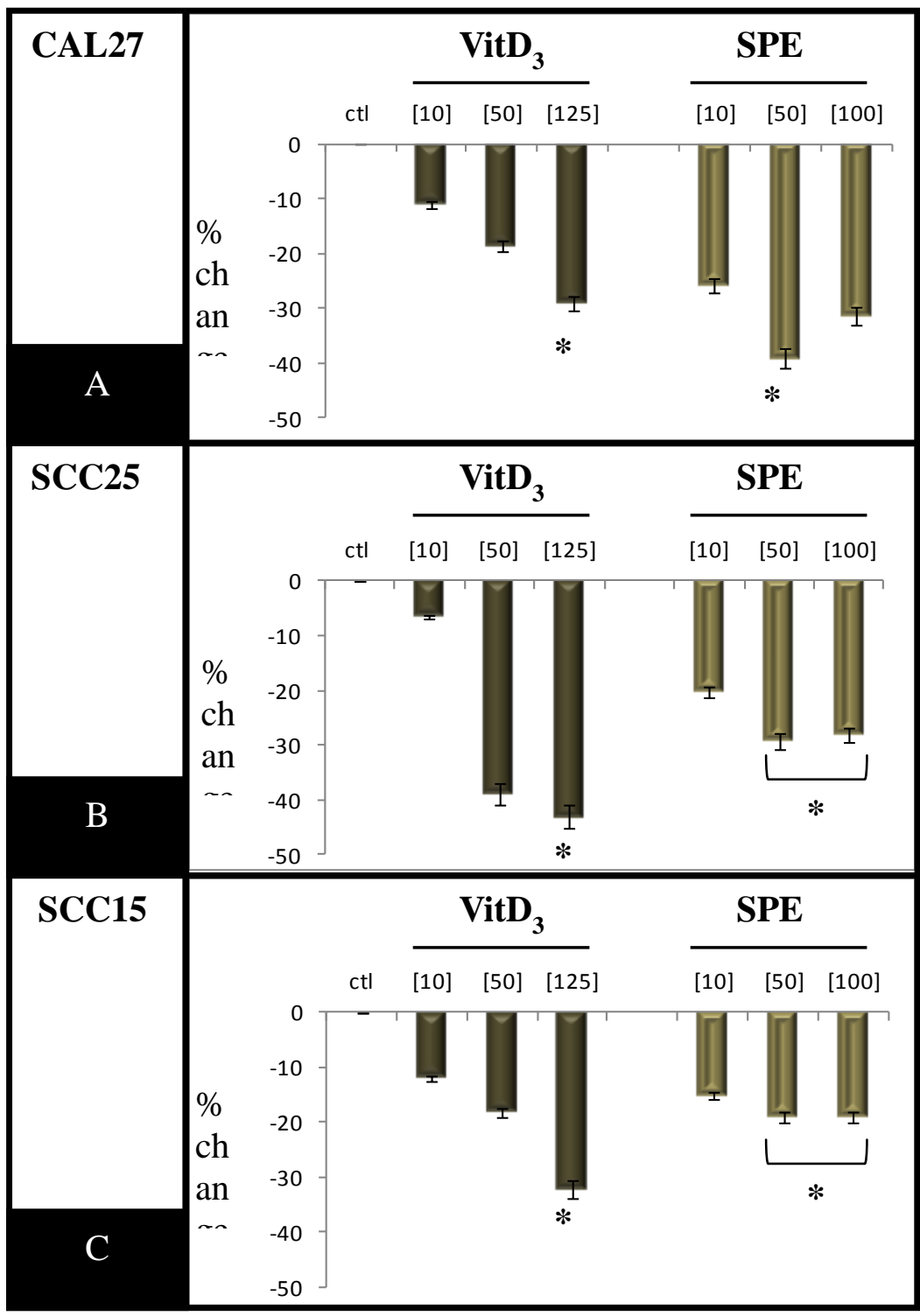

Figure 1. Oral cancer proliferation inhibition by VitD3, or SPE administration. (A) Three day growth of CAL27 was significantly inhibited by increasing concentrations of $\mathrm{VitD}_{3}(10 \mathrm{nmol},-11 \%$; $50 \mathrm{nmol}$, 18.6\%, $125 \mathrm{nmol},-29.1 \%)$ and SPE (10 nmol, $-25.8 \%$; $50 \mathrm{nmol},-39.1 \%$; $100 \mathrm{nmol},-31.3 \%)$ compared with baseline controls. (B) SCC25 growth was also inhibited by $\mathrm{VitD}_{3}(10 \mathrm{nmol},-6.5 \% ; 50 \mathrm{nmol},-38.8 \%, 125 \mathrm{nmol},-43.1 \%)$ and SPE (10 nmol, -20.2\%; $50 \mathrm{nmol},-29.2 \%$; $100 \mathrm{nmol},-28.1 \%)$. (C) SCC15 inhibition by $\mathrm{VitD}_{3}(10 \mathrm{nmol},-12 \%$; 50 nmol, $-18.2 \%, 125 \mathrm{nmol},-32.1 \%)$ and SPE (10 nmol, -15.2\%; $50 \mathrm{nmol},-19.2 \%$; $100 \mathrm{nmol},-19.1 \%$ ) was similar. Note: $*$ denotes growth inhibitory maximum $\left(\mathrm{GI}_{\mathrm{MAX}}\right)$.

Higher concentrations of SPE were then evaluated in combination with low-dose $\mathrm{VitD}_{3}$ to ascertain any differential effects on cellular growth inhibition. Although the combination of $\mathrm{VitD}_{3}[\mathrm{~L}]$ and SPE $[\mathrm{H}]$ reduced growth in all three cell lines, this inhibition was nearly equivalent to the effects observed with $\mathrm{VitD}_{3}[\mathrm{~L}]$ and SPE [L]. In brief, CAL27 growth was 
inhibited by $41.5 \%$, which was greater than the effects of $\mathrm{VitD}_{3}[\mathrm{~L}](-18.6 \%)$ or SPE $[\mathrm{H}](-$ $39.1 \%)$ alone, but indistinguishable from the results of the first combination trial $(-41.8 \%$, $p>0.5$ ). A similar result was observed in SCC15 cells, which were inhibited by $33.2 \%$, which was consistent with the previous combination $(-31.2 \%, \mathrm{p}>0.5)$, but greater than either $\mathrm{VitD}_{3}[\mathrm{~L}]$ $(-18.2 \%)$ or SPE $[\mathrm{H}](-19.2 \%)$ in isolation. The growth of SCC25 cells was not significantly altered by the increased concentration of SPE $(-32.1 \%$ versus $-37.1 \%)$ and was similar to the results with either $\mathrm{VitD}_{3}[\mathrm{~L}](-38.8 \%)$ or SPE [H] $(-29.2 \%)$ alone.

Interestingly, when the $\mathrm{GI}_{\mathrm{MAX}}$ concentration of $\mathrm{VitD}_{3}[\mathrm{H}]$ was combined with the $\mathrm{GI}_{\mathrm{MAX}}$ concentration of SPE [H], growth was nearly completely inhibited. Growth in CAL27 cells was inhibited by $83.1 \%$, by $80.1 \%$ in SCC 15 cells, and by $81.2 \%$ in SCC 25 cells. These effects were significantly greater than any other combination or single treatment evaluated for all three cell lines $(p<0.01)$. Finally, each combination and the $\mathrm{GI}_{\mathrm{MAX}}$ concentrations for each variable were tested on the normal oral gingival cell line (HGF-1), which exhibited no growth inhibition, but rather stimulation of cell proliferation, which ranged between $18.2 \%$ and $41.2 \%$.

To determine if the growth inhibitory effects of $\mathrm{VitD}_{3}$ or SPE administration on these cell lines was due, at least in part, to alterations in cell survival or viability - each cell line and experimental treatment was analyzed at each time point of the proliferation assays and the viability assessed (Table 1). This analysis revealed that $\mathrm{VitD}_{3}$ and SPE administration was sufficient to decrease viability among the oral cancer cell lines. More specifically, the baseline viability of CAL27 cells (94.4\%) was lowered by $\mathrm{VitD}_{3}[\mathrm{~L}]$ to $71.1 \%$ and more considerably by $\mathrm{VitD}_{3}[\mathrm{H}]$ to $50 \%$. SCC25 (90.5\%) and SCC15 (93.1\%) viability was also diminished by $\mathrm{VitD}_{3}$ [L] $(72.3 \%, 68.2 \%)$ and more drastically by $\mathrm{VitD}_{3}[\mathrm{H}](53.1,61.3 \%)$. Although SPE administration was sufficient to reduce viability, these reductions were less dramatic and did not differ significantly between the low- and the high-concentrations. For example, SPE administration decreased CAL27 viability (94.4\%) to $88.2 \%$ and $84.6 \%$ under SPE [L] and SPE $[\mathrm{H}]$ administration, respectively. SCC25 and SCC15 viability was similarly reduced by the addition of SPE [L] $(85.2 \%, 84.7 \%)$ and SPE $[\mathrm{H}](82.5 \%, 81.3 \%)$.

Table 1. Cell viability.

$$
\operatorname{VitD}_{3}[L] \quad \operatorname{VitD}_{3} \quad \text { SPE }[L] \quad \text { SPE }[H]
$$

$[\mathrm{H}]$

$\begin{array}{llllll}\text { CAL27 } & 94.4 \% & 71.1 \% & 50.0 \% & 88.2 \% & 84.6 \% \\ \text { SCC25 } & 90.5 \% & 72.3 \% & 53.1 \% & 85.2 \% & 82.5 \% \\ \text { SCC15 } & 93.1 \% & 68.2 \% & 61.3 \% & 84.7 \% & 81.3 \%\end{array}$

\begin{tabular}{|c|c|c|c|c|c|}
\hline & & $\operatorname{VitD}_{3}[\mathrm{~L}]$ & $\operatorname{VitD}_{3}[\mathrm{~L}]$ & $\begin{array}{l}\operatorname{VitD}_{3} \\
{[\mathrm{H}]}\end{array}$ & $\begin{array}{l}\operatorname{VitD}_{3} \\
{[\mathrm{H}]}\end{array}$ \\
\hline & & SPE [L] & SPE $[H]$ & SPE [L] & SPE $[H]$ \\
\hline CAL27 & $94.4 \%$ & $66.4 \%$ & $63.3 \%$ & $48.2 \%$ & $23.4 \%$ \\
\hline SCC25 & $90.5 \%$ & $67.1 \%$ & $62.6 \%$ & $47.2 \%$ & $19.6 \%$ \\
\hline SCC15 & $93.1 \%$ & $65.1 \%$ & $61.8 \%$ & $51.3 \%$ & $14.9 \%$ \\
\hline
\end{tabular}


The $\mathrm{GI}_{\mathrm{MAX}}$ concentration of $\mathrm{VitD}_{3}[\mathrm{H}]$ was then combined with the low-dose of SPE [L], which resulted in a significant change in growth inhibition in all three cell lines. CAL27 growth, for example, was inhibited by $45.1 \%$, which was greater than the inhibition observed under either previous combination $(-41.8 \%$ and $-41.5 \%)$ or either alone $(-29.1 \%,-39.1 \%)$. Similar results were observed for SCC15 $(-47.3 \%)$ and SCC25 $(-53.2 \%)$, which was also greater than either previous combination examined (SCC15: -31.2\%, -33.2\%; SCC25: $-37.1 \%,-32.1 \%$ ) or $\mathrm{VitD}_{3}[\mathrm{H}](\mathrm{SCC} 15,-32.1 \%$; SCC25, -43.1\%) or SPE [L] (SCC15, -15.2\%; SCC25, -29.1\%).

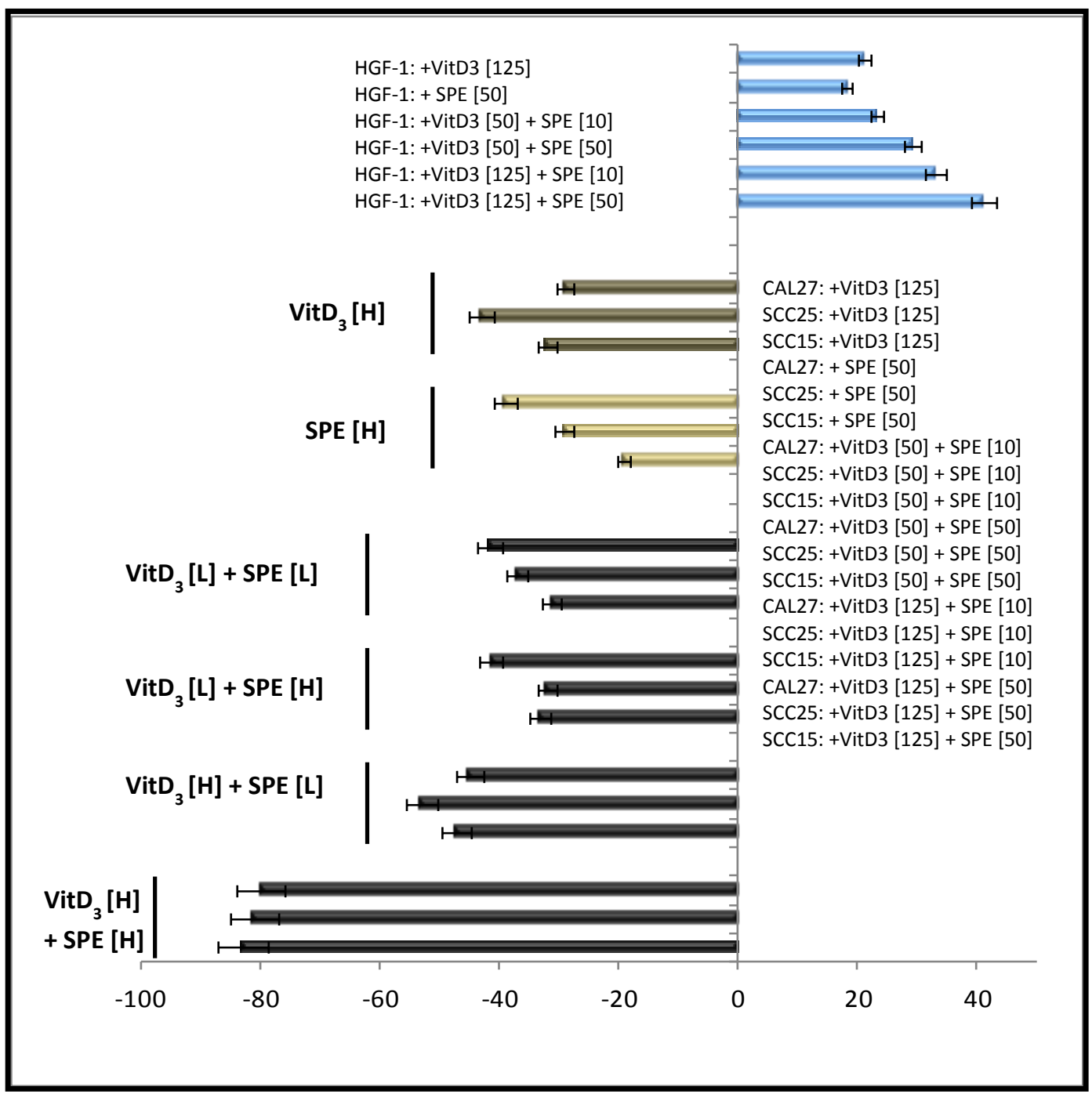

Figure 2. Effects of combined $\mathrm{VitD}_{3}$, and SPE administration on proliferation. The combined effect of the lowest $\mathrm{VitD}_{3}[\mathrm{~L}]$ and SPE [L] concentrations inhibited CAL27, SCC25, and SCC15 growth by 41.8\%, 37.1\%, and $31.2 \%$. VitD $3[\mathrm{~L}]$ and the $\mathrm{GI}_{\mathrm{MAX}}$ concentration of SPE $[\mathrm{H}]$ inhibited CAL27, SCC25, and SCC15 growth by $41.5 \%, 32.1 \%$, and $33.2 \%$. The $\mathrm{GI}_{\mathrm{MAX}}$ concentration of $\mathrm{VitD}_{3}[\mathrm{H}]$ combined with the low-dose of SPE [L] inhibited CAL27, SCC25, and SCC15 growth by $45.1 \%, 53.2 \%$, and $47.3 \%$. The $\mathrm{GI}_{\mathrm{MAX}}$ concentrations of both $\mathrm{VitD}_{3}[\mathrm{H}]$ and SPE $[H]$ inhibited growth more robustly in CAL27, SCC25, and SCC15 cells $(-83.1 \%,-81.2 \%$, and $-80.1 \%)$. 
The combined administration of $\mathrm{VitD}_{3}$ and SPE had more variable effects. To illustrate, the viability of CAL27, SCC25 and SCC15 was reduced under VitD 3 [L] with either SPE [L] $(66.4 \%, 67.1 \%, 65.1 \%)$ or SPE $[\mathrm{H}](63.3 \%, 62.6 \%, 61.8 \%)$ administration to levels that were lower than either $\mathrm{VitD}_{3}$ or SPE alone (but were not dissimilar between these treatment groups). However, the treatment with $\mathrm{VitD}_{3}[\mathrm{H}]$ combined with SPE [L] dramatically reduced viability among these three cell lines $(48.2 \%, 47.2 \%, 51.3 \%)$. Furthermore, the combined treatment of these cells with $\mathrm{VitD}_{3}[\mathrm{H}]$ combined with and SPE $[\mathrm{H}]$ had more drastic effects on viability and cell survival $(23.4 \%, 19.6 \%$, and $14.9 \%)$.

To determine if the growth inhibitory and viability reducing effects of VitD3 and SPE administration were associated with differential gene expression, relative endpoint (RE) RT-PCR was performed on total RNA isolated from each cell line following combination therapy using oligonucleotide primers specific to the mRNA of critical apoptosis regulatory genes caspase-2 (an apoptosis initiator), caspase-8 (an apoptosis effector), and bax, as well as the cell-cycle regulatory genes $c$-myc, ornithine decarboxylase (ODC) and the tumor suppressor, p53 (Figure 3). Three $\mathrm{VitD}_{3}$ - SPE combinations were evaluated due to their differential effects on growth, as well as viability. These experimental conditions included $\mathrm{VitD}_{3}[\mathrm{~L}]-\mathrm{SPE}[\mathrm{L}], \mathrm{VitD}_{3}[\mathrm{H}]-\mathrm{SPE}$ $[\mathrm{L}]$, and $\mathrm{VitD}_{3}[\mathrm{H}]-\mathrm{SPE}[\mathrm{H}]$. This analysis revealed that the caspase initiator and effector, caspase- 2 and caspase- 8 exhibited barely detectable mRNA expression under $\mathrm{VitD}_{3}$ [L] - SPE [L] administration, although expression increased markedly under both $\mathrm{VitD}_{3}[\mathrm{H}]-\mathrm{SPE}[\mathrm{L}]$ and $\mathrm{VitD}_{3}[\mathrm{H}]$ - SPE $[\mathrm{H}]$ administration. The expression of bax mRNA, which was easily observed in all cell lines in every condition, also increased under all three experimental treatment conditions.

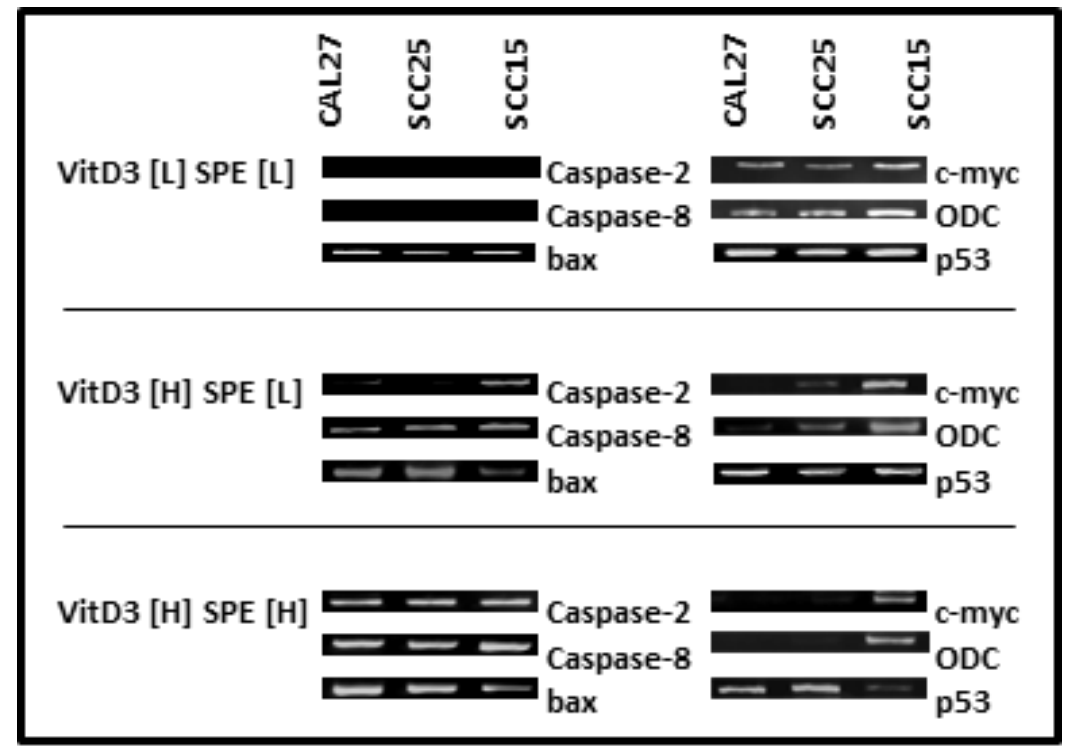

Figure 3. Relative endpoint RT-PCR analysis. Relative endpoint (RE) RT-PCR was performed on total RNA extracted from CAL27, SCC25 and SCC15 cells under combination treatments of $\mathrm{VitD}_{3}[\mathrm{~L}]-\mathrm{SPE}[\mathrm{L}], \mathrm{VitD}_{3}$ $[\mathrm{H}]$ - SPE [L], and $\mathrm{Vit}_{3}[\mathrm{H}]$ - SPE $[\mathrm{H}]$. These treatments induced mRNA expression of all apoptosis-related genes, caspase-2, caspase-8, and bax. The most marked changes in mRNA expression of cell-cycle related genes, $c$-myc and $O D C$ were observed under $\mathrm{VitD}_{3}[\mathrm{H}]-\mathrm{SPE}[\mathrm{H}]$ administration. 
An analysis of the cell-cycle regulatory genes, c-myc, ODC and the tumor suppressor p53 revealed active mRNA expression in all three cell lines under $\mathrm{VitD}_{3}[\mathrm{~L}]$ - SPE [L] administration. However, the increased administration of $\mathrm{VitD}_{3}[\mathrm{H}]-\mathrm{SPE}[\mathrm{L}]$ and $\mathrm{VitD}_{3}[\mathrm{H}]-$ SPE $[\mathrm{H}]$ induced decreased expression of both $c$-myc and $O D C$. Interestingly, no observable changes in mRNA expression of the tumor suppressor p53, which has been found to be actively transcribed in all three cell lines, were observed except in SCC15 cells under the most concentrated treatment condition: $\mathrm{VitD}_{3}[\mathrm{H}]-\mathrm{SPE}[\mathrm{H}]$.

\section{DISCUSSION:}

The overall objective of this study was to evaluate the anti-cancer properties of soy protein extract (SPE), which is available as a dietary supplement and most closely resembles the whole soy food that most US adults are likely to consume as edamame, tofu, or other soy-based products. The effects of SPE against well-characterized oral cancer cell lines were evaluated using in vitro analysis methods in conjunction with administration of Vitamin D to determine the interactive effects of SPE on Vitamin D-induced oral cancer growth inhibition. Based upon previous work that determined SPE and Vitamin D are each, independently sufficient to mediate the proliferative phenotypes of these cancers in this experimental model, the working hypothesis was that co-administration would synergistically amplify these effects. These results of this study clearly demonstrated these anti-tumor effects, which are consistent with previous reports and observations. However, this may be the first study to evaluate the co-administration of SPE and Vitamin D, as well as the first to report synergistic effects on growth inhibition of oral cancer cell lines (under conditions of Vitamin D GI MAX concentrations).

Although this type of research has been extremely useful for identifying agents that are now clinically demonstrated as effective agents against specific cancers, a number of limitations must be considered when evaluating the outcomes of this study. First, one limitation of this and other preclinical studies involves the use of oral cancer cell lines, as there may be underlying dissimilar genetic mutations that might potentially influence the experimental outcomes. For example, the SCC25 cell line has been found to contain a deletion in the cdk1 promoter that contains a key transcriptional repressor region [60]. In addition, the CAL27 cell line contains a nonsense mutation in the SMAD4 gene, while SCC15 cells were found to harbor a missense mutation in SMAD2 - both signal TGF- $\beta$ transduction proteins [61]. Finally, both CAL27 and SCC15 cells contain a single nucleotide polymorphism in the S100A2 gene, a calcium-binding tumor suppressor protein, although this does not appear to alter their propensity for growth, migration or invasion [62]. However, a growing body of evidence demonstrates that deregulation and reduced expression of key tumor suppressors, such as p16, in these cell lines may, in fact, be the result of hyper methylation - providing further justification to elucidate the interconnected roles of dietary components and transcriptional regulation in the growth and progression of oral cancers [63-65].

Another limitation to be considered is that SPE, unlike Vitamin D, contains multiple bioactive substances in addition to the soy isoflavones (Daidzein, Genistein, Glycitein), which may have direct effects on cellular behaviors despite their relatively low concentrations [66, 67]. These SPE components include, but are not limited to, phytates (inositol hexaphosphate), oligosaccharides, saponins, Kunitz inhibitor and Bowman-Birk Inhibitor (BBI) [68]. Some 
previous studies have demonstrated that saponins were capable of exerting growth inhibiting effects on colon cancer cell lines in vitro [62, 69, 70]. In addition, other studies have demonstrated cytotoxicity and apoptotic effects on oral cancers in vitro using saponins [71-73]. However, these effects in animal and human models may be severely limited due to low absorption rates, as well as extremely low serum concentrations that are far lower than the experimental concentrations that were evaluated [66, 67].

Finally, some recent studies have demonstrated there may be possible adverse effects of elevated $25(\mathrm{OH}) \mathrm{D}$ concentrations on cancer risk in prostate, breast, pancreas, and esophageal cancers, suggesting that these effects may depend on dose, timing and duration of exposure, as well as tissue specific, lifestyle, and genetic factors [74, 75]. Although J- or U-shaped risk curves have been proposed to describe the noted associations in these studies, confounding factors present in the original studies are likely responsible for these findings [51, 74]. For example, outcomes of intervention trials of supplemental Vitamin D were inconclusive due to the lack of baseline vitamin $\mathrm{D}$ status reports of trial participants and consequent dose adequacy estimates $[51,74,75]$. This may suggest that studies focused on the dose administered, rather than their effect on alleviating deficiency, achieving adequacy, or adding to pre-trial adequate serum levels, might have significantly affected the dose-response curves and further complicated the interpretation of trial outcomes.

\section{CONCLUSION:}

Although many clinical studies have suggested Vitamin D status, intake, and supplementation may have significant effects on oral cancer risk, progression, and mortality, growing epidemiologic evidence now suggests that dietary patterns, which may include the intake of other cancer preventing foods (such as soy) may influence these effects $[1,6]$. This study is among the first to examine the relationships between Vitamin D and soy administration in oral cancer cells, which provides specific information about the mechanisms and pathways that may be modulated along with growth inhibition and reduced viability. This study provides the first direct evidence of the magnitude of these relationships, which may be particularly useful to oncologists, oral health researchers, and nutrition epidemiologists as they analyze and develop rubrics for generalizing the health protective effects of diet and dietary supplements, as well as the most effective ancillary treatment options for patients with oral cancer.

\section{List of abbreviations:}

Soy protein extract (SPE); ornithine decarboxylase (ODC), United States (US), oral and pharyngeal cancers (OPC), human papillomavirus (HPV), vitamin D receptor (VDR), retinoid X receptor (RXR), Dulbecco's Modified Eagle's Medium (DMEM), 4-2-hydroxyethyl-1piperazineethanesulfonic acid (HEPES), fetal bovine serum (FBS), 1,25-dihydroxyvitamin $\mathrm{D}_{3}$ $\left(\mathrm{VitD}_{3}\right)$, molecular weights $(\mathrm{MW})$, null hypothesis $\left(\mathrm{H}_{0}\right)$, analysis of variance (ANOVA), lowest concentration [L], growth Inhibitory Maximum (GI MAX), highest concentration [H], glyceraldehyde 3-phosphate dehydrogenase (GAPDH), human gingival fibroblasts (HGF-1), minimum threshold cycle (CT), saturation cycle (CS), relative endpoint polymerase chain reaction (RE) RT-PCR, ethidium-bromide (EtBr), Bowman-Birk Inhibitor (BBI). 


\section{Competing interests:}

The authors declare they have no financial or non-financial competing interests and report no conflicts of interest relevant to the contents of this article. No funding was obtained from any company or pharmaceutical organization.

\section{Authors' contributions:}

KK, MAK, and CJB conceived and designed this project and were responsible for performing the experimental assays, data collection, figure generation, and writing. Karl Kingsley, Mark Keiserman, Christine J Bergman.

\section{Acknowledgements and Funding:}

This research was supported, in part, by an Institutional Research Grant award from the American Cancer Society to KK (ACS-IRG\#103719), the University of Nevada, Las Vegas (UNLV) Office of Sponsored Programs, the UNLV School of Dental Medicine (UNLV-SDM), and the UNLV-SDM Department of Biomedical Sciences and Office of Research.

\section{REFERENCES}

1. Swango PA: Cancers of the oral cavity and pharynx in the United States: an epidemiologic overview. J Public Health Dent 1996, 56:309-318.

2. Blot WJ, McLaughlin JK, Winn DM, Austin DF, Greenberg RS, Preston-Martin S, Bernstein L, Schoenberg JB, Stemhagen A, Fraumeni JF Jr. Smoking and drinking in relation to oral and pharyngeal cancer. Cancer Res. 1998, 489:3282-3287.

3. Curado MP, Hashibe M. Recent changes in the epidemiology of head and neck cancer. Curr Opin Oncol. 2009, 21(3):194-200.

4. Chaturvedi AK. Epidemiology and clinical aspects of HPV in head and neck cancers. Head Neck Pathol. 2012, 6 Suppl 1:S16-24. Epub 2012 Jul 3.

5. Saman DM. A review of the epidemiology of oral and pharyngeal carcinoma: update. Head Neck Oncol. 2012, 4:1.

6. Garavello W, Lucenteforte E, Bosetti C, La Vecchia C. The role of foods and nutrients on oral and pharyngeal cancer risk. Minerva stomatologica. 2009;58(1-2):25-34.

7. Lucenteforte E, Garavello W, Bosetti C, La Vecchia C. Dietary factors and oral and pharyngeal cancer risk. Oral oncology. 2009;45(6):461-467.

8. Pavia M, Pileggi C, Nobile CGA, Angelillo IF. Association between fruit and vegetable consumption and oral cancer: a meta-analysis of observational studies. Am J Clin Nutr. 2006, 83: 1126-1134.

9. Hsu S, Singh B, Schuster G. Induction of apoptosis in oral cancer cells: agents and mechanisms for potential therapy and prevention. Oral Oncol. 2004, 40:461-473.

10. Terry P, Terry JB, Wolk A. Fruit and vegetable consumption in the prevention of cancer: an update. J Intern Med. 2001, 250: 280-90.

11. Park EJ, Pezzuto JM. Botanicals in cancer chemoprevention. Cancer Metastasis Rev. 2002, 2: 231-255.

12. Jane-Salas E, Chimenos-Kustner E, Lopez-Lopez J, Rosello-Llabres X. Importance of diet in the prevention of oral cancer. Med Oral 2003, 8: 260-268. 
13. Sakagami H, Jiang Y, Kusama K, Atsumi T,Ueha T, Toguchi M, Iwakura I, Satoh K, Fukai T, Nomura T. Induction of apoptosis by flavones, flavonols (3-hydroxyflavones) and isoprenoid-substituted flavonoids in human oral tumor cell lines. Anticancer Res. 2000, 20: 271-277.

14. Ferguson PJ, Kurowska E, Freeman DJ, Chambers AF, Koropatnick DJ. A flavonoid fraction from cranberry extract inhibits proliferation of human tumor cell lines. J Nutr. 2004, 134(6): 1529-1535.

15. Ferguson PJ, Kurowska EM, Freeman DJ, Chambers AF, Koropatnick. In vivo inhibition of growth of human tumor cell lines by flavonoid fractions from cranberry extract. $J$ Nutr Cancer. 2006, 56(1):86-94.

16. King M, Chatelain K, Farris D, Jensen D, Pickup J, Swapp A, O’Malley S, Kingsley K. Oral squamous cell carcinoma proliferative phenotype is modulated by proanthocyanidins: a potential prevention and treatment alternative for oral cancer. $B M C$ Complement Altern Med. 2007, 7: 22.

17. Chatelain K, Phippen S, McCabe J, Teeters CA, O’Malley S, Kingsley K. Cranberry and grape seed extracts inhibit the proliferative phenotype of oral squamous cell carcinomas. Evid Based Complement Alternat Med. 2008 [epub ahead of print].

18. Kresty LA, Howell AB, Baird M. Cranberry proanthocyanidins induce apoptosis and inhibit acid-induced proliferation of human esophageal adenocarcinoma cells. J Agric Food Chem. 2008, 56(3): 676-680.

19. Kingsley K, Jensen D, Toponce R, Dye J, Martin D, Phippen S, Ross D, Halthore VS, O'Malley S. Inhibition of Oral Cancer Growth in Vitro Is Modulated Through Differential Signaling Pathways by Over-the-Counter Proanthocyanidin Supplements. J Diet Suppl. 2010, 7(2): 130-144.

20. Elattar TM, Virji AS. The inhibitory effect of curcumin, genistein, quercetin and cisplatin on the growth of oral cancer cells in vitro. Anticancer Res. 2000, 20(3A): 1733-1738.

21. Ye F, Wu J, Dunn T, Yi J, Tong X, Zhang D. The inhibition of cyclooxygenase-2 activity in head and neck cancer cells by genistein. Cancer Lett. 2004, 211(1): 39-46.

22. Browning AM, Walle UK, Walle T. Flavonoid glycosides inhibit oral cancer cell proliferation - role of cellular uptake and hydrolysis to the aglycones. J Pharm Pharmacol. 2005, 57(8): 1037-1042.

23. Johnson TL, Lai MB, Lai JC, Bhushan A. Inhibition of cell proliferation and MAP kinase and Akt pathways in oral squamous cell carcinoma by genistein and biochanin A. Evid Based Complement Alternat Med. 2008 [Epub ahead of print].

24. Kingsley K, Truong K, Low E, Hill CK, Chokshi SB, Phipps D, West MA, Keiserman MA, Bergman CJ. Soy protein extract (SPE) exhibits differential in vitro cell proliferation effects in oral cancer and normal cell lines. J Diet Suppl. 2011 Jun;8(2):16988.

25. Matsukawa Y, Marui N, Sakai T, Satomi Y, Yoshida M, Matsumoto K, Nishino H, Aoike A. Genistein arrests cell cycle progression at G2-M. Cancer Res. 1993, 53: 1328-1331.

26. Perabo FG, Von Low EC, Ellinger J, von Rucker A, Muller SC, Bastian PJ. Soy isoflavone genistein in prevention and treatment of prostate cancer. Prostate Cancer Prostatic Dis. 2008, 11: 6-12. 
27. Hsu A, Bray TM, Helferich WG, Doerge DR, Ho E. Differential effects of whole soy extract and soy isoflavones on apoptosis in prostate cancer cells. Exp Biol Med (Maywood). 2010, 235 (1): 90-97.

28. Ju YH, Doerge DR, Woodling KA, Hartman JA, Kwak J, Helferich WG. Dietary genistein negates the inhibitory effect of letrozole on the growth of aromatase-expressing estrogen-dependent human breast cancer cells (MCF-7Ca) in vivo. Carcinogenesis. 2008, 29(11): 2162-2168.

29. Singh-Gupta V, Zhang H, Yunker CK, Ahmad Z, Zwier D, Sarkar FH, Hillman GG. Daidzein effect on hormone refractory prostate cancer in vitro and in vivo compared to genistein and soy extract: potentiation of radiotherapy. Pharm Res. 2010 [Epub ahead of print].

30. Cross HS, Kállay E, Khorchide M, Lechner D. Regulation of extrarenal synthesis of 1,25dihydroxyvitamin D3--relevance for colonic cancer prevention and therapy. Mol Aspects Med. 2003 Dec;24(6):459-65. Review.

31. Cross HS, Kállay E, Lechner D, Gerdenitsch W, Adlercreutz H, Armbrecht HJ. Phytoestrogens and vitamin D metabolism: a new concept for the prevention and therapy of colorectal, prostate, and mammary carcinomas. J Nutr. 2004, 134(5):1207S-1212S. Review.

32. Swami S, Krishnan AV, Moreno J, Bhattacharyya RB, Peehl DM, Feldman D. Calcitriol and genistein actions to inhibit the prostaglandin pathway: potential combination therapy to treat prostate cancer. $J$ Nutr. 2007, 137(1 Suppl):205S-210S.

33. Bartik L, Whitfield GK, Kaczmarska M, Lowmiller CL, Moffet EW, Furmick JK, Hernandez Z, Haussler CA, Haussler MR, Jurutka PW. Curcumin: a novel nutritionally derived ligand of the vitamin $\mathrm{D}$ receptor with implications for colon cancer chemoprevention. J Nutr Biochem. 2010, 21(12):1153-61.

34. Chen G, Kim SH, King AN, Zhao L, Simpson RU, Christensen PJ, Wang Z, Thomas DG, Giordano TJ, Lin L, Brenner DE, Beer DG, Ramnath N. CYP24A1 is an independent prognostic marker of survival in patients with lung adenocarcinoma. Clin Cancer Res. 2011, 17(4):817-26. Epub 2010 Dec 17.

35. Suetani RJ, Ho K, Jindal S, Manavis J, Neilsen PM, Pishas KI, Rippy E, Bochner M, Kollias J, Gill PG, Morris HA, Callen DF. A comparison of vitamin D activity in paired non-malignant and malignant human breast tissues. Mol Cell Endocrinol. 2012, 362(12):202-10.. Epub 2012 Jun 29.

36. García-Quiroz J, García-Becerra R, Barrera D, Santos N, Avila E, Ordaz-Rosado D, Rivas-Suárez M, Halhali A, Rodríguez P, Gamboa-Domínguez A, Medina-Franco H, Camacho J, Larrea F, Díaz L. Astemizole synergizes calcitriol antiproliferative activity by inhibiting CYP24A1 and upregulating VDR: a novel approach for breast cancer therapy. PLoS One. 2012;7(9):e45063. Epub 2012 Sep 12.

37. Kállay E, Adlercreutz H, Farhan H, Lechner D, Bajna E, Gerdenitsch W, Campbell M, Cross HS. Phytoestrogens regulate vitamin D metabolism in the mouse colon: relevance for colon tumor prevention and therapy. J Nutr. 2002, 132(11 Suppl):3490S-3493S.

38. Giovannucci E. Vitamin D status and cancer incidence and mortality. Advances in experimental medicine and biology. 2008, 624:31-42. 
39. Krishnan AV, Trump DL, Johnson CS, Feldman D. The role of vitamin D in cancer prevention and treatment. Endocrinology and metabolism clinics of North America. 2010, 39(2):401-418.

40. Yin L, Grandi N, Raum E, Haug U, Arndt V, Brenner H. meta-analysis: serum vitamin D and breast cancer risk. Eu J Cancer. 2010, 46(12):2196-2205.

41. Fleet JC, DeSmet M, Johnson R, Li Y. Vitamin D and cancer: a review of molecular mechanisms. Biochem J. 2012, 441(1):61-76.

42. Shils ME, Shike M. Modern Nutrition In Health And Disease: Lippincott Williams \& Wilkins; 2006.

43. Lou YR, Molnar F, Perakyla M, et al. 25-Hydroxyvitamin D(3) is an agonistic vitamin D receptor ligand. The Journal of steroid biochemistry and molecular biology. 2010, 118(3): 162-170.

44. Fedirko V, Bostick RM, Flanders WD, Long Q, Shaukat A, Rutherford RE, Daniel CR, Cohen V, Dash C. Effects of vitamin D and calcium supplementation on markers of apoptosis in normal colon mucosa: a randomized, double-blind, placebo-controlled clinical trial. Cancer Prev Res (Phila). 2009, 2(3): 213-23.

45. Kizildag S, Ates H, Kizildag S. Treatment of K562 cells with 1,25-dihydroxyvitamin D3 induces distinct alterations in the expression of apoptosis-related genes BCL2, BAX, BCLXL, and p21. Ann Hematol. 2010, 89(1): 1-7.

46. Akutsu N, Lin R, Bastien Y, et al. Regulation of gene Expression by 1alpha,25dihydroxyvitamin D3 and Its analog EB1089 under growth-inhibitory conditions in squamous carcinoma Cells. Molecular endocrinology (Baltimore, Md.). 2001, 15(7): 1127-1139.

47. Lin R, Nagai Y, Sladek R, et al. Expression profiling in squamous carcinoma cells reveals pleiotropic effects of vitamin D3 analog EB1089 signaling on cell proliferation, differentiation, and immune system regulation. Molecular endocrinology (Baltimore, Md.). 2002, 6(6):1243-1256.

48. Ha PK, Chang SS, Glazer CA, Califano JA, Sidransky D. Molecular techniques and genetic alterations in head and neck cancer. Oral oncology. 2009, 45(4-5): 335-339.

49. Cadoni G, Boccia S, Petrelli L, et al. A review of genetic epidemiology of head and neck cancer related to polymorphisms in metabolic genes, cell cycle control and alcohol metabolism. Acta Otorhinolaryngol Ital. 2012, 32(1): 1-11.

50. Zeljic K, Supic G, Stamenkovic Radak M, Jovic N, Kozomara R, Magic Z. Vitamin D receptor, CYP27B1 and CYP24A1 genes polymorphisms association with oral cancer risk and survival. Journal of oral pathology \& medicine : official publication of the International Association of Oral Pathologists and the American Academy of Oral Pathology. 2012, 41(10): 779-787.

51. Heaney RP. Vitamin D--baseline status and effective dose. NEJM 2012, 367(1):77-78.

52. Hedlund TE, Maroni PD, Ferucci PG, Dayton R, Barnes S, Jones K, Moore R, Ogden LG, Whala K, Sackett HM, Gray KJ. Long-term dietary habits affect soy isoflavone metabolism and accumulation in prostatic fluid in Caucasian men. J Nutr. 2005, 135: 1400-1406. 
53. Hedlund TE, van Bokhoven A, Johannes WU, Nordeen SK, Ogden LG. Prostatic fluid concentrations of isoflavonoids in soy consumers are sufficient to inhibit growth of benign and malignant prostatic epithelial cells in vitro. Prostate. 2006, 66: 557-566.

54. Adlercreutz H, Markkanen H, Watanable S. Plasma concentrations of phyto-estrogens in Japanese men. Lancet. 1993, 342: 1209-1210.

55. Morton MS, Arisaka O, Miyake N, Morgan LD, Evans BA. Phytoestrogen concentrations in serum from Japanese men and women over forty years of age. J Nutr. 2002, 132: 3168 -3171 .

56. Hays WL. Statistics. 5. International Thomson Publishing; 1994. Inferences about population means; pp. 311-42.

57. Bernard-Gallon DJ, Satih S, Chalabi N, Rabiau N, Bosviel R, Fontana L, Bignon YJ. Phytoestrogens regulate the expression of genes involved in different biological processes in BRCA2 knocked down MCF-7, MDA-MB-231 and MCF-10a cell lines. Oncol Rep. 2010, 23(3): 647-653.

58. Xu B, Chang SK, Liu Z, Yuan S, Zou Y, Tan Y. Comparative studies on the chemical and cell-based antioxidant activities and antitumor cell proliferation properties of soy milk manufactured by conventional and commercial UHT methods. J Agric Food Chem. 2010, 58(6): 3558-3566.

59. Cederroth CR, Nef S. Soy, phytoestrogens and metabolism: A review. Mol Cell Endocrinol. 2009, 304(1-2): 30-42. Epub 2009 Mar 9. Review.

60. Dahler AL, Jones SJ, Dicker AJ, Saunders NA. Keratinocyte growth arrest is associated with activation of a transcriptional repressor element in the human cdk1 promoter. $J$ Cell Physiol. 1998, 177(3):474-482.

61. Qiu W, Schonleben F, Li X, Su GH. Disruption of transforming growth factor beta-Smad signaling pathway in head and neck squamous cell carcinoma as evidenced by mutations of SMAD2 and SMAD4. Cancer Lett. 2007, 245(1-2):163-170.

62. Tsai WC, Lin YC, Tsai ST, Shen WH, Chao TL, Lee SL, Wu LW. Lack of modulatory function of coding nucleotodie polymorphism S100A2 $185 \mathrm{G}>$ A in oral squamous cell carcinoma. Oral Dis. 2011, 17(3):283-290.

63. Yang YY, Woo ES, Reese CE, Bahnson RR, Saijo N, Lazo JS. Human metallothionein isoform gene expression in cisplatin-sensitive and resistant cells. Mol Pharmacol. 1994, 45(3):453-460.

64. Timmermann S, Hinds PW, Munger K. Re-expression of endogenous p16ink4a in oral squamous cell carcinoma lines by 5 -aza-2'-deoxycytidine treatment induces a senesencelike state. Oncogene. 1998, 17(26):3445-3453.

65. Chang X, Monitto CL, Demokan S, Kim MS, Chang SS, Zhong X, Califano JA, Sidransky D. Identification of hypermethylated genes associated with cisplatin resistance in human cancers. Cancer Res. 2010, 70(7):2870-2879.

66. Messina MJ. Legumes and soybeans: overview of their nutritional profiles and health effects. Am J Clin Nutr. 1999, 70(3 Suppl): 439S-450S.

67. Friedman M, Brandon DL. Nutritional and health benefits of soy proteins. $J$ Agric Food Chem. 2001, 49(3): 1069-1086. Review. 
68. Csáky I, Fekete S. Soybean: feed quality and safety. Part 1: biologically active components. A review. Acta Vet Hung. 2004, 52(3): 299-313.

69. Kennedy AR. The evidence for soybean products as cancer preventive agents. J Nutr. 1995, 125(3 Suppl): 733S-743S.

70. MacDonald RS, Guo J, Copeland J, Browning JD Jr, Sleper D, Rottinghaus GE, Berhow MA. Environmental influences on isoflavones and saponins in soybeans and their role in colon cancer. J Nutr. 2005, 135(5): 1239-42.

71. Furuya S, Takayama F, Mimaki Y, Sashida Y, Satoh K, Sakagami H. Cytotoxic activity of saponins from Camassia leichtlinii against human oral tumor cell lines. Anticancer Res. 2001, 21(2A): 959-64.

72. Bachran C, Heisler I, Bachran D, Dassler K, Ervens J, Melzig MF, Fuchs H. Chimeric toxins inhibit growth of primary oral squamous cell carcinoma cells. Cancer Biol Ther. 2008, 7(2): 237-42. Epub 2007 Nov 3.

73. Susanto H, Fakhrudin N, Murti YB, Supriatno, Siswomiharjo W. Saponins from Plumeria acuminata Ait induce cell growth inhibition and apoptosis of oral squamous carcinoma cells. Chin J Dent Res. 2010, 13(2): 153-6.

74. Grant WB. Ecological studies of the UVB-vitamin D-cancer hypothesis. Anticancer Res. 2012, 32(1): 223-236.

75. Toner CD, Davis CD, Milner JA. The vitamin D and cancer conundrum: aiming at a moving target. J Am Diet Assoc. 2010, 110(10), 1492-1500. 